Utah State University

DigitalCommons@USU

$10-10-2018$

\title{
Despite Our Best Intention: Students Relate How Social Promotion Hurt Them and What Changes They Believe Will Help Them
}

Toby McMahon

Utah State University

Follow this and additional works at: https://digitalcommons.usu.edu/soc_stures

Part of the Anthropology Commons

Recommended Citation

McMahon, T. Interchange (2018) 49: 499. https://doi.org/10.1007/s10780-018-9344-3

This Article is brought to you for free and open access by the Sociology, Social Work and Anthropology Student Works at DigitalCommons@USU. It has been accepted for inclusion in Sociology, Social Work and Anthropology Student Research by an authorized administrator of DigitalCommons@USU. For more information, please contact digitalcommons@usu.edu.

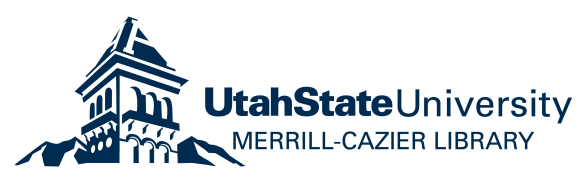




\section{Despite Our Best Intention: \\ Students Relate How Social Promotion Hurt Them and What Changes They Believe will Help Them}




\begin{abstract}
The paper researches the practice of social promotion, where students who fail due to a lack of comprehension of grade level material are promoted along with their classmates who passed. Student and parent interviews, student surveys, and data from students' graduation records are used to determine that social promotion does not improve the students' education, instead students who are socially promoted are more likely to dropout of high school, less likely to graduate high school on time or at all, and the alternative practices are needed if students are to be successful and graduate high school.
\end{abstract}




\section{Introduction}

Commonly referred to as social promotion, some failing students are pushed onto the next grade along with their peers who passed. If students begin to see passing grades as an entitlement rather than an incentive or consequence for working hard, the value of education is decreased. According to the 2017 National Assessment of Education Progress 37\% of high school seniors test proficient on reading and only $25 \%$ are proficient in math (Fiore et al., 2017). Since many students are moved on, they may reason that if the material was important, then they would be required to learn it, but since the material is not required and the need to understand it ignored, it must not be important. While social promotion may be common in some middle schools, it is not the practice in high schools and students are required to repeat courses until they receive a passing grade. Consequently, such students upon beginning in High School may immediately experience failure because they are unprepared for the high school experience.

Dropping out of high school, or failing to graduate, is a lengthy process which happens over a period of years. There are factors which can indicate which students are at a higher risk for dropping out and they can be identified in the first few grades of elementary school (Lloyd, 1978: Ensminger, 1992) and in middle school (Kaplan, 1997). The more positive experiences a student has, the more likely they are to graduate (Drewry, 2010). Some factors are outside the school system ((Roderick, 1994) or student's realm of influence, including family income, mother's expectation (Ensminger, 1992), father's occupation, parents' marital status (Lloyd, 1978), race, or sex (Cairns, 1989). Some factors are environmental including teacher rejection or deviation peers (Kaplan, 1997). Others dynamics are of the student's own making, including grades and test scores (Lloyd, 1978) and disruptive behavior (Vitaro, 1999). 
Retention, especially repetitive retention, also increases likelihood of student's dropping out (Cairns, 1989; Roderick, 1994). The highest rate of student failure in high school is the ninth grade and a disproportionate number of students who later drop out are first retained in ninth grade (Dockery, 2012). Students can be identified as high risk of dropping out at an early age with relative confidence: including 75\% accuracy while in the third grade (Lloyd, 1978) and $100 \%$ accuracy if the student fails three grades before high school (Cairns, 1989). Students who are retained due to a lack of learning opportunities, rather than ability, are the most likely to benefit from retention (Jimerson, 2012) because the second time they are either more familiar with the material and approach the material with a different attitude (Fanguy, 2012).

Students who are retained early (such as in third grade) are more successful compared to students who are socially promoted (Lorence, 2014; Cham, 2015). They not only have substantial short-term gains in math and reading achievement but the probability of being retained in later grades is decreased (Schwerdt, 2012) and it does not negatively affect their academic achievement or educational motivation in high school (Hughes, 2017). Even secondary students who are retained because of academic performance gain short-term benefits (Klapproth, 2016).

The contrasting practice of promoting students who have not gained an understanding of the essential material and concepts so they can stay with their age group peers, has led to students expecting something for nothing, a public perception of weakening of standards, and parents suing for educational malpractice because students were not prepared for upper levels (Owings, 2001). Social promotion also changes the paradigm of the school from (1) an emphasis on merit to an emphasis on efficiency; (2) a focus on individual to group learning; (3) a belief in different capability to equal capability; (4) adjusting student to school to adjusting the school to 
the student; and (5) a focus on the best students to the average students (Hernandez-Tutop, 2012).

The purpose of this study was to look at social promotion and retention from the viewpoint of the student to determine whether students see social promotion or retention helping them. From this can then be identified practices that middle and high Schools could adopt to increase student learning and decrease failures.

\section{Methodology}

There were three segments of this study that involved analysis of school records, interviews with students and parents and a survey of students who had experienced retention in some form. This provided information on effects of social promotion and retention on a graduating class of students, personal accounts showing how students are individually affected, and how student's attitudes towards education as a group are influenced by the practice of retention and social promotion, respectively.

The high school involved had $~ 1100$ students and was in a rural area in a town with a population of $\sim 10,000$. Approximately $50 \%$ of students were Caucasian, $35 \%$ AfricanAmerican, and 15\% Hispanic. Fifty-eight percent of students qualified for free or reduced lunch. The school has earned a graduation rate of $84 \%$ and a dropout rate of $3 \%$.

Approval was granted for examination of student records of the high school graduating classes for 2013, 2014, and 2015 on the basis that the records could not leave the student services office and no students' names were recorded. The number of students who had or had not been socially promoted was tabulated. Also, from the most recent graduation class were recorded graduation rates, grade retentions, and number of dropouts. Graduation rates were considered 
based on those students who graduated in 8 semesters or less. Grade retention was based on students who were not promoted one grade level following two semesters. To be considered to have dropped out of school, students entered high school, still lived in the school district, but no longer attended school and had not earned a diploma. Students, who take longer than 4 years to graduate, but did so before turning 21 where not included in the study. The objective was to identify any correlation between social promotion in elementary and middle school and high school success.

All students who entered the high school during the same year were examined as part of data collection, whether they graduated on time, graduated early, have been retained and will be graduating later, or dropped out. Students who started high school and then transferred to a different school or moved out of the county were not included; neither were students who transferred in during their high school years. If no elementary and middle school data was available the student's data was not used. Most student records started containing grades in third grade, when students started taking North Carolina End of Grade tests, so kindergarten, first grade, and second grade data was not available and so it was not possible to tell if a student was socially promoted before third grade.

Questions for the survey were developed based on suggestions and comments from the interviews and were conducted using surveymonkey.com. The survey contained 26 questions, (24 in which students could answer whether they strongly agree, agree, were neutral, disagree, or strongly disagree with various practices and statements, and two open ended questions) and delivered to 161 students who were in Algebra 1 or Geometry classes. The majority of students were freshman, in either their first year in high school or repeating as freshman, however some 
were sophomores or juniors. Students were informed that the results would be confidential and that their names would not be used and their specific answers would not be known.

Permission was obtained to interview 3 students ( 2 boys and one girl) who had been in high school at least 2 years (so they had time to become comfortable and understand the procedures of the school) and who had been socially promoted in middle school. The interviews focused on practices and policies which either helped the students or obstructed their education. These were students who failed at least one middle school grade, particularly math courses, and were moved on to high school. The students were selected from a repeater Algebra I course, which means they took Algebra I as freshman and failed the course and are now taking Algebra I for at least a second time, and were considered repeat freshman. These students had been in high school at least two years. A portion of students would have been socially promoted; some would have failed math classes in high school while the rest have passed every course they have taken. They would all have either been retained as freshman or have classmates who were retained their freshman year. Students would also have had classmates who had failed a course and therefore repeated the same course rather than moving on.

The students were asked questions about (1) their personal experiences in high school, (2) their opinions on social promotion, (3) what schools could do to help them, and (4) what advice they would give themselves if they were back in middle school but knew what they did now.

For the parent interview, two parents were chosen, both female. Both had students currently in public schools, and one also had a student who had graduated high school. They were asked questions about their experiences with and opinions on social promotion with follow-up questions based upon their responses. For the elementary school student interviews, 3 students 
were chosen, 2 boys and one girl. Two of the students were in fourth grade and the other was in fifth grade.

The objectives of the interviews were to understand how successful the students feel they have been in high school, to learn about their experiences, and whether they feel that social promotion in middle school helped them in high school. They were questioned about different practices that they thought would have benefitted them to make the transition into high school easier. Parents were questioned about their experience with education, their expectations, and their interactions with their students.

\section{Findings}

\section{Outcomes of Social Promotion}

Of the 476 student records included in the study, $96 \%$ of students who dropped out had been socially promoted at least 3 times, the other $4 \%$ had been socially promoted twice (Fig. 1). In every case the first social promotion occurred in elementary school, in either third, fourth, or fifth grade. If a student had been social promoted 3 times, $89 \%$ of them dropped out and did not finish high school (Fig. 2). In contrast, only 3\% of students who had been socially promoted twice dropped out. This confirms the findings of Cairns (1989) that being socially promoted 3 times is an indicator of future lack of success for a student in high school.

As shown in Fig. 1, of those students who should have graduated but were still in high school, $98 \%$ had been socially promoted at least once with $86 \%$ having been socially promoted twice. In contrast, students who graduated in 4 years, only $18 \%$ had been socially promoted at all, and only $5 \%$ more than once. Only one student who had been socially promoted 3 times from 
elementary school to middle school graduated on time. While social promotion has the aim of keeping students with their age group peers, $90 \%$ of students who had been socially promoted twice were still in high school while their peers had graduated. Only $7 \%$ graduated on-time with their peers.

Being socially promoted more than once increases the likelihood that students will be retained in the ninth grade. At this high school, to be promoted from ninth grade to tenth grade, students are required to pass English 1 plus 5 other classes (from a total of 8 classes they take). Students who had been socially promoted at least three times were $100 \%$ retained in ninth grade (Fig. 3).The number of classes students passed their freshman year was proportional to their social promotion (Fig. 4). Students who had been socially promoted three or more times passed an average only 1.8 classes with physical education being the class most likely passed. Of the 38 students who failed all 8 classes their freshman year, all had been socially promoted at least three times.

Since students at this high school needed to earn 28 credits (out of 32 credits possible during their 4 years, students can fail one class a year and still graduate on time. Every student who had been socially promoted in elementary or middle school but still graduated on time failed at least one class while in high school. Math, English, and Science classes made up 93\% of those classes.

Being social promoted only once was less detrimental to the students' success in high school. This group consisted of 46 of the 476 student records used in this study as not one of them dropped out of high school. Seventy-six percent of them graduated on time while the remainder were retained. Not unexpectedly, the most successful group of students were those who had never been socially promoted and passed every class during elementary school and 
middle school. Ninety-eight percent graduated on time, $2 \%$ were retained and none of them dropped out (Fig. 2).

\section{Student Experiences}

When asked about their experiences in high school, the students did not think that middle school prepared them for the extent they would need to work when they were in $9^{\text {th }}$ grade at high school, especially in math (see Table A). Their middle school experience had been that school was mostly games, listening to the teacher was no important and things were "handed to you." It was in high school that they realized you had to take things seriously and you have to "do it yourself." The math is harder and "if you don't know it you get behind." Making this transition from thinking "school is just games" is important because the student came come into high school thinking “it's just $9^{\text {th }}$ grade" and then realize if they don't take school seriously "it's going to come back and get you later." To these students, $9^{\text {th }}$ grade became their "most serious year in high school."

All three students responded in the interviews that social promotion does not help the students (see Table B). They now recognized that by being socially promoted in middle school students miss information that is important when they get to high school and this has a continual effect on grades. Being socially promoted did not help in preparing them to be self-reliant when they came to high school. The students' opinion was that being held back because of failure would have been better because it would help them to know that schooling "is serious" and they need to "do everything yourself." Social promotion fosters the expectation of passing a grade without any effort while being held back would help students understand they need to "earn it" and would give them "a reason to do the best I can." 
In retrospect, their advice to middle school students based upon what they would tell themselves if they could go back in time is to take school seriously. Do your work. Listen to your teachers. Stop playing. Do everything right because “when you get to $12^{\text {th }}$ grade you're going to need all this stuff." Realize that freshman year in high school will not be the same as middle school and you need to "push harder and do it."

\section{Parent Experiences}

From a parent's perspective, social promotion tended to undermine both the parent's and the teachers' credibility with students (see Table C). And students then do not see the importance of applying themselves to learning, until they are actually failed in a class in high school.

\section{Elementary School Student Attitudes}

The three elementary students who were interviewed had similar attitudes towards social promotion as shown in Table $\mathrm{D}$ that suggests they also each had a positive viewpoint of completing homework and schoolwork. They wanted to succeed and thought that social promotion has a negative impact on both the students being socially promoted and to themselves.

\section{Freshman Experiences}

Most students believe that failure can be a good motivator: $88.2 \%$ agree that the possibility of failing motivates students to work harder. Surveyors were split on the belief that holding back students who failed did not improve the long term chance for success, $29.2 \%$ agree and $38.5 \%$ disagree, and also that retention made students more likely to drop out of high school, $49.1 \%$ agree compared to $21.0 \%$ disagree. They did however, disagree with the statement that once a student fails once they are more likely to fail in the future, $54.0 \%$. They also said that while failing freshman year of high school did not decrease the chances of graduating, $63.9 \%$, failing 
did hurt students' self-esteem, 76.5\%. Over 93\% said that home life and parent's attitude affects student performances, however they did not feel that economic status played a role in the failure rate, $73.9 \%$. While a majority of students felt that failing a class was grounds for retaking the class, 58.4\%, a higher percentage felt that failing state tests, known as EOCs or EOGs, was an indicator that the class should be retaken, $72.7 \%$. The majority of students were willing to place the blame of failing on the student, $72.0 \%$, while concluding that blame should not be placed on either the teachers, $72.6 \%$ or parents, $75.8 \%$. Summer school, $75.7 \%$, and after school tutoring, $72.7 \%$, were seen as positive interventions for students who were failing. Only $26.1 \%$ thought that promoting a student who failed helped the student, while $78.9 \%$ felt that promoting student who failed lessens the value of education and $66.4 \%$ of students believed that once a student who fails is promoted they expect to pass regardless of grade.

Some additional observations from the student are: failing may hurt student's self-esteem, but it makes students work harder; failing freshman year does not make one less likely to graduate and promoting a failing student does not help them, and it is not better to promote then retain. If there were only two options, social promotion or retention, these findings would be a paradox. However, the students overwhelmingly support after school tutoring and summer school as solutions for helping students. They seem to understand that students do better when with students their own age, that outside help is sometimes needed, but having a consequence is needed as a motivational tool. The concept of learning step one before moving onto step two is also shown where the vast majority said that failing a class justifies repeating that class.

Students were also asked two additional questions in the survey: "What can a school system do to help students who failed a class?" and "What can a school do to prevent students from failing a class?" In response to the first question, the most common suggestions were 
tutoring, including mandatory tutoring, credit recovery, shorter after school classes to focus on what the student did not understand, and figure out why they failed the class. When prompted about what could be done to prevent failing, students suggested pay more attention to individuals, tutoring, summer class, Saturday school, and study hall, find new methods for learning style, smaller classes, teach only the information that is useful as too much material in class does not help.

\section{Discussion and Implications}

Students provide a unique picture of school, because it is their life and their reality. They spend the majority of their waking hours either in school or doing activities which are school related. In addition, students can be brutally honest and tell it how it is, or at least how they perceive that it is. Students recognize that outside forces factor influence outcome in the classroom. They overwhelmingly feel that parental attitude is a factor in the classroom, but the parents finances are not. Even though students believe a parent's attitude and home life influences the student, if the student fails, students do not but the blame on the teachers or the parents, but rather on the student. This shows that even though students are molded and subjected to the world around them, they understand that in high school they need to assume responsibility for their actions. In the world of education the eternal debate is whether to socially promote students who do not have the skills necessary to succeed or to retain students, place them with younger students, and potentially embarrass them for the remainder of the school years. It has always been one or the other. Both methods seem to be focused on the end result at the end of the school year, rather than on practices which prevents the end result from occurring. Failure and retention should be in place as a motivating factor, rather than as a punishment. The students showed that after 
school tutoring and summer school were better than either social promotion or retention. The next step would be to identify other practices which can be used to increase education before the retention/social promotion decision needs to be made. Middle schools and high schools need to develop solutions for failing students. Also with the majority of students saying that the switch from middle school to high school is difficult, high schools and middle school need to work together to make the transition easier and smoother for the students. Finally, the state tests need to be changed. When students do not feel that failing a test shows need to repeat a class the test is not an effective tool of measurement. There is a disconnect between the test and what the test is trying to accomplish and while that disconnect is there students will not perform well on the test.

Despite what students and the data confirm, students are still being socially promoted. Edmund Burke famously said "all that is necessary for the triumph of evil is that good men do nothing." To apply Burke to education "All that is necessary for students to fail, is for good schools to do nothing." Students fail, they are socially promoted, and then they become someone else's problem. Many times teachers and schools do not have a choice; they must move all students to the next grade. The paradigm needs to change to one of "the buck stops here." Students who do not understand material need to held accountable and learn it. As the data from the high school graduates shows, students who are socially promoted are more likely to dropout or not graduate on time. Simply put, social promotion does not help students graduate high school either on time or at all. A student who is socially promoted three times did not graduate on time and a student who passed all their classes did not drop out. Students who were socially promoted at least twice may graduate, but it will take them longer and it will not be with peers their own age, making it less likely they will go to college. This is ironic, because a major 
agreement for social promotion is so that a student can stay with peers their own age. They may spend elementary school and middle school with those students, but they do not walk across the stage and receive their diploma with those same students, it is with students who are younger than they are. Another way to look at this is: at least three teachers out of six, third grade to eighth grade inclusive said that the student did not have the knowledge, or at least has not shown through a year of testing and assignments, and has not proven that they have the knowledge, of the current level. Fifty percent of a student's teachers did not feel that the student would be successful moving on, yet moving on they did. The student did not understand the material they were given, therefore they were given more material and more advanced material. They do not learn adding, subtracting, multiplication, or division, so let's give them fractions. They do not understand fractions, so let's put them in a class with rational expression and tell them to simplify. When they cannot do that we give them rational equations and tell them that this is what they have been doing for year, it is just a little more advance. If the students could not do it when it was simple, why should they get it when it is complicated?

However, failure and retention should be a motivator and a last resort, not a first response. Students should be given options. After school tutoring (Nelson-Royes, 2013), peer tutoring (Song, 2018), Saturday school (Drake, 2017), summer school (Jacob 2004, 2009), and credit recovery are interventions schools can use to help students achieve success. These were items which students proposed as opportunities for helping them be successful in school. A school can tell a student, "You can pass on your own, go to Saturday tutoring, go to summer school, or repeat the grade." One can compare that message, which says that the material the student is being taught is important and the student will be held responsible, to the message students currently get, which is one of "Who cares? If you do the work you are moving on, if 
you do not do the work, you are moving on. The work is not important; we cannot care if you learn it."

Getting parents involved is also needed, especially in elementary and middle school (Hill, 2009 and 2016) to help students overcome small problems before they grow out of control. Parents understand their child and know what motivates them (Muller, 1993). They can also work with the teacher to help the student. When a student comes home the parent can reinforce what the teacher has been teaching all day. The parent does not need to understand what the student is learning, but rather emphasize that the material and school is important. The author has had different interactions with parents. One parent told their student that since they did not understand the math the student was doing, the math was not important. Another parent told they child that the parent did not understand the math, but they expected the student to do the work and complete the assignment, because they would need it later in college or working. The same situation led to two completely different outcomes. Not all parents will help and support the teacher and school, but those that do are worth their weight in gold and will provide success to their students.

The old saying "An ounce of prevention is worth a pound of cure" certainly applies to social promotion, retention, and success in school. The earlier problems can be identified and failures caught the better education students will have. If students are failing under the current system, they have little chance for success under the increased and more rigorous standards on the Common Core. More is going to be expected from the students, the expectations and standards are rising, the amount of time a teacher can spend reviewing past material is decreasing. Students need to come into a class ready for that class, they cannot come in 
expecting to have six to eight weeks of review before learning new material. Students needs to rise to the challenge, failure now will lead to failure in the future.

\section{Conclusion}

Failing students do not have the necessary knowledge and skills to succeed in school and life. By socially promoting students, schools are essentially doing nothing. The Common Core Standards are being put in place to raise the expectations of the students, yet social promotion has the opposite effect. Schools need to do something or students will continue to fail and leave school shortchanged and unprepared for college and the real world. 


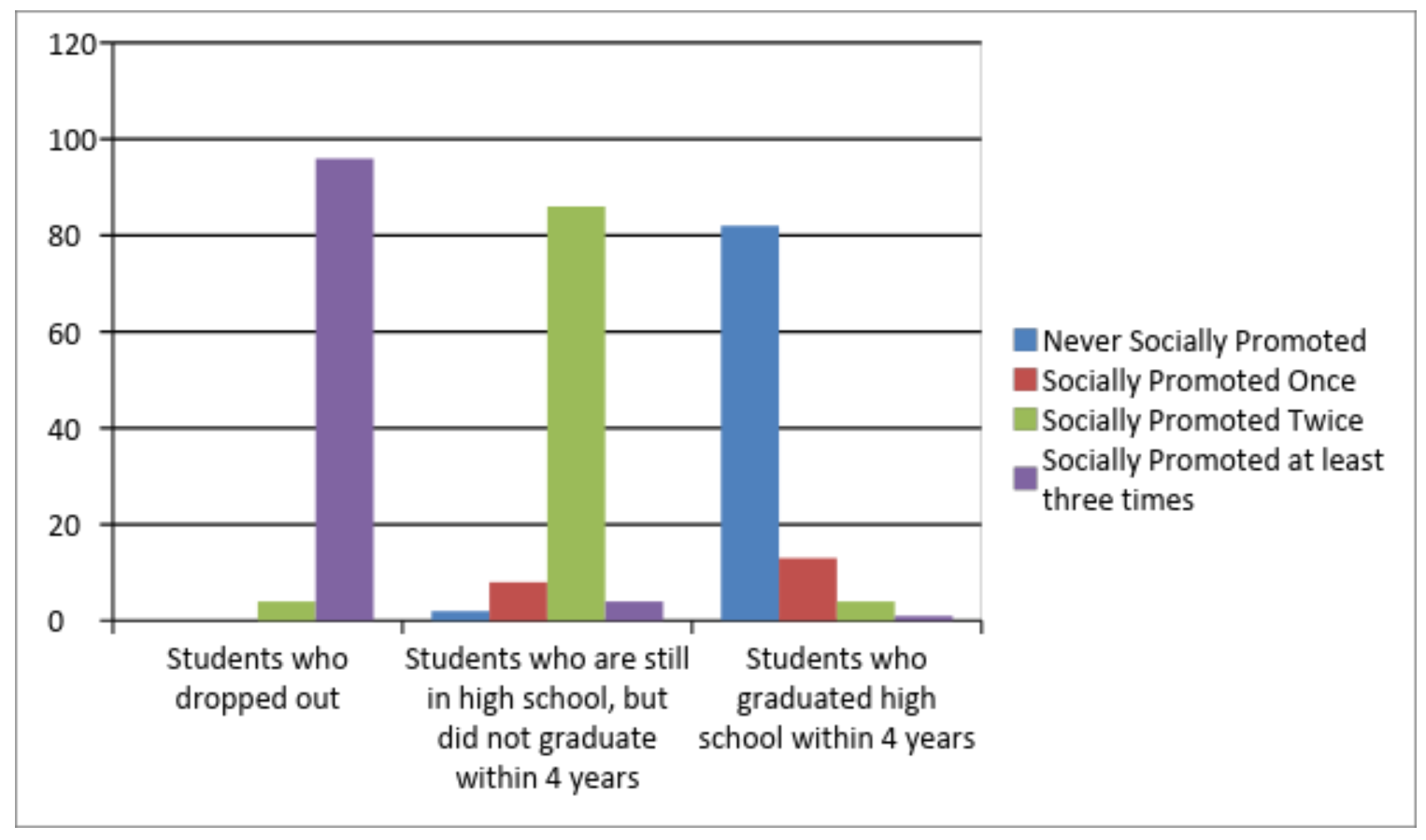

Fig. 1

Graduation outcomes expressed as number of students based on social promotion.

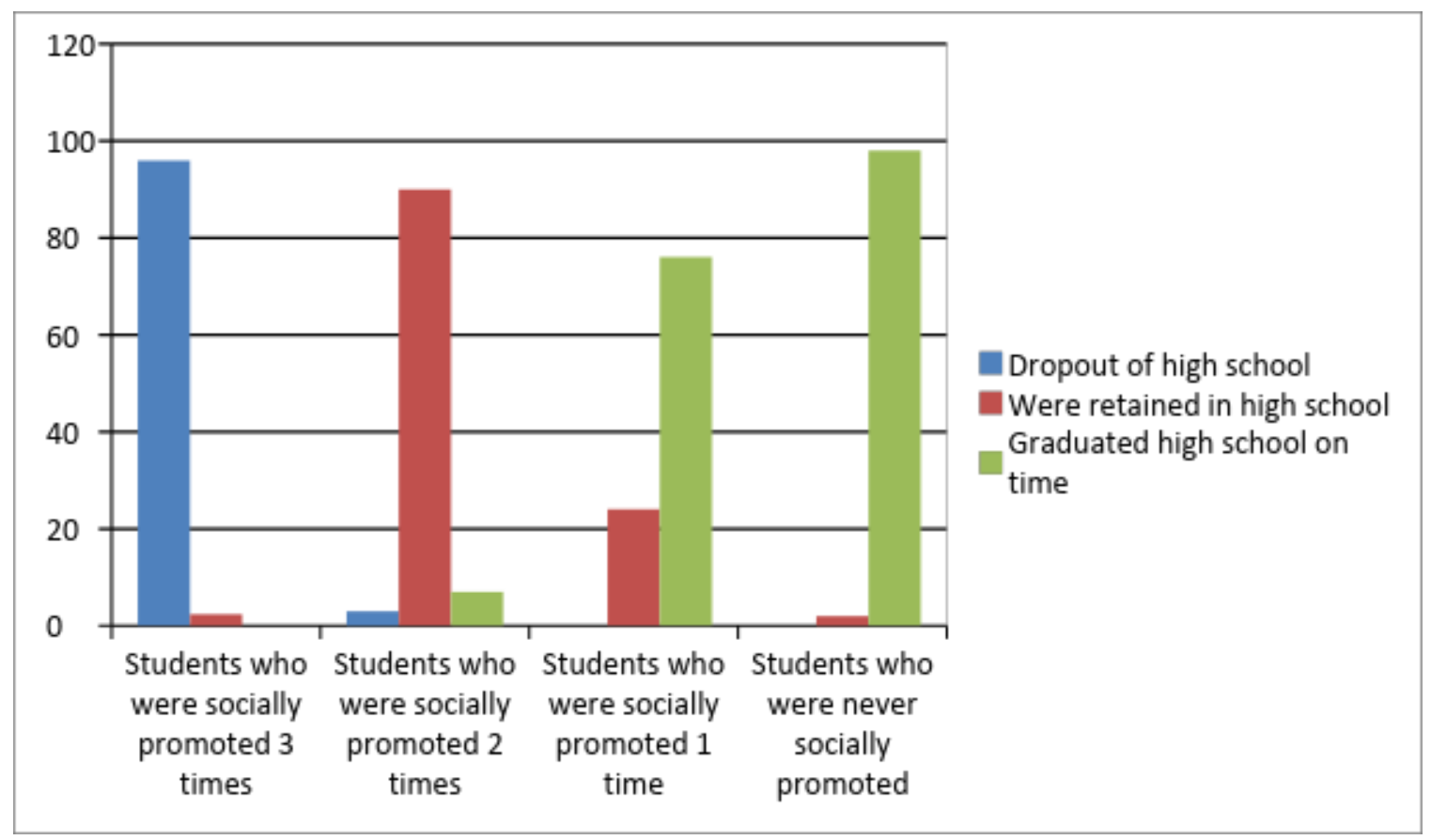

Fig. 2

Student outcomes expressed as a percentage based upon number of times socially promoted. 


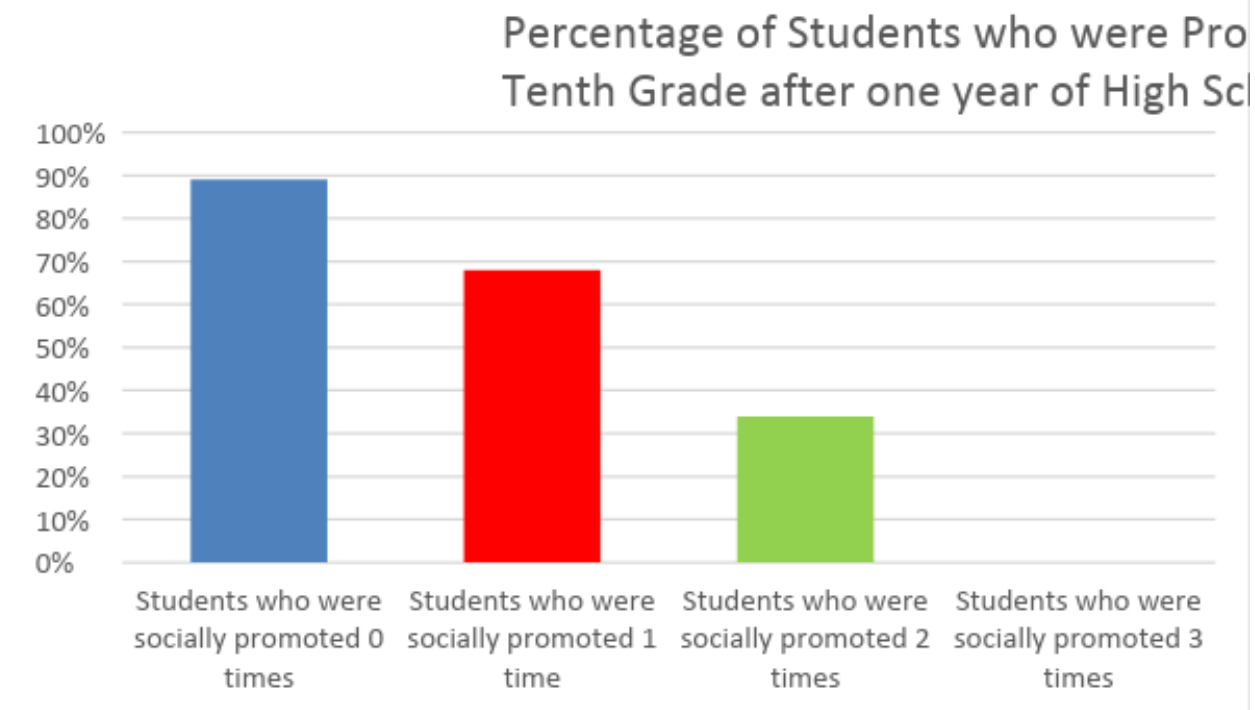

Table 3

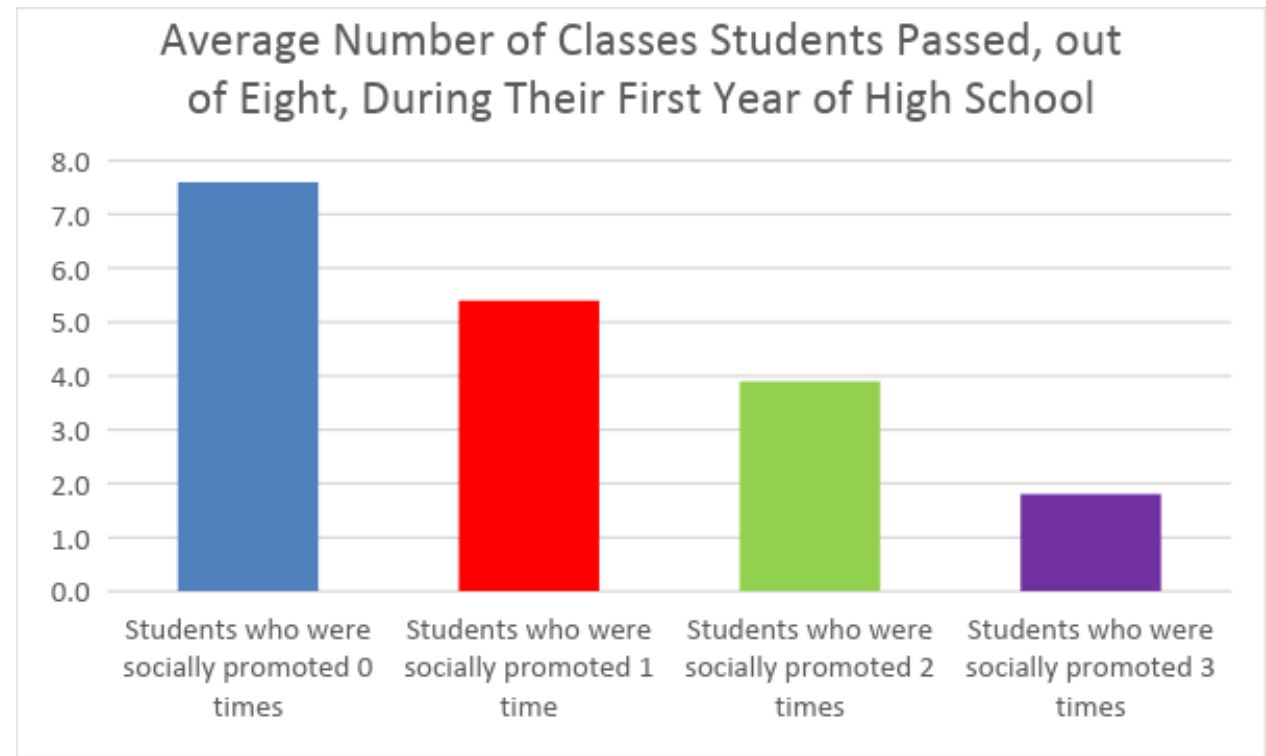

Table 4

Table A Examples of student comments regarding their experiences in $9^{\text {th }}$ grade.

Terrible. When the teacher teaches, you got to listen and you can't zone out. Cause you missed the whole process

It is completely different. I think the math taught at middle schools is simply for middle school. When you got to high school it is different and more advanced

Middle School was easier; it was just handed to you. When you get to High School, you got to do it yourself. I wasn't prepared for it at all 
When I came out of middle school I thought everything was games. But you realize that high school you really have to take serious

My GPA is really quite low right now because I didn't take school seriously in $9^{\text {th }}$ grade. I think $9^{\text {th }}$ grade is your most serious year in high school, even though you are thinking like 'it's just $9^{\text {th }}$ grade,' it's going to come back and get you later

It gets harder after your freshman year, especially in math. So if you don't know it, you get behind.

Table B Examples of student comments regarding social promotion in middle school

If you do terrible in $7^{\text {th }}$ grade they let you go to $8^{\text {th }}$ grade, $9^{\text {th }}$ grade, $10^{\text {th }}$, you're going to
eventually miss something very important that you should have went back and redid. I'd
rather get held back to know that it is serious and take it more seriously
If they just move you, you never understand or get what you were supposed to in middle
school to help you high school. It affects your grades.
Social promotion does not help at all, nowhere does it help. Because when you get to high
school you got to do everything yourself. In middle school if you fail, then the kid going to
expect to pass, because they did it before. If middle school is supposed to be preparing for
high school then they're not doing it right. They're just giving it to the kids instead of making
them earn it
If I would have got held back, then I would have been like 'I can't get held back again.' It
would have given me a reason to do the best I can. Cause I wouldn't want to be held back.'

Table C Parents' comments regarding social promotion in middle school

It is really frustrating to take your son to Open House, before the school year starts, and have some kid tell the teacher "I am not going to do anything, so don't ask me a question, don't give me homework, and you are going to pass me because you have to." It dampens the start of the school year."

When your child comes home, in tears, worried that if she doesn't pass the test she will be held back, because that's what the teacher told her, and then she sees that students who don't pass the test move on with everyone else. Eventually, students realize that the teacher is lying. It teaches the students not to believe the teacher

One of the problems with the teacher lying about failing a student, is that when the students get to high school, they don't believe the teachers. When a teacher tells them that they will repeat every class that they fail, the students just think that this is what the teacher has to say, but it really isn't going to happen. It is only after they fail, do they finally believe the teachers, but then they have wasted a year of high school.

Table D Examples of elementary school student attitudes toward social promotion. 


If you can't do $4^{\text {th }}$ grade work, there no way you can do $5^{\text {th }}$ grade stuff. I need to learn the
stuff now to do good next year
It teaches kids that school isn't important, that you don't need to know the stuff your teacher
teaches you."
Lots of kids in my class don't do homework, because they don't want to do it, and they know
they are going on to fifth grade next year.
If you got to know what the teachers teaches to be good at school, then you should stay in
grade until you get it
It sucks, because you try hard to do your work, and the other kids don't, but next year you will
be in the same class again. I don't think it is fair.
There are days when I'm tired and it's late, and I don't what to do my homework, and I say to
myself "it doesn't matter, I will be in 5th grade anyway." It's a bad thought and I don't like
it."


Bibliography

Cairns, R,, Cairns, B., \& Neckerman, H. (1989). Early school dropout: configurations and determinants. Child Development, 60(6), 1437-1452.

Cham, H., Hughes, J. N., West, S. G., \& Im, M. H. (2015). Effect of retention in elementary grades on grade 9 motivation for educational attainment. Journal of School Psychology, 53(1), 724.

Davoudzadeh, P., McTernan, M.L., \& Grimm, K.J. (2015). Early school readiness predictors of grade retention from kindergarten through eighth grade: A multilevel discrete-time survival analysis approach. Early Childhood Research Quarterly, 32, 183-192.

Dockery, D. (2012) School dropout indicators, trends, and interventions for school counselors. Journal of School Counseling, 10(12). Retrieved from http://files.eric. ed.gov/fulltext/EJ978868.pdf

Drake, K. J Educ Change (2017) 18: 337. https://doi.org/10.1007/s10833-017-9302-3

Drewry, J., Burge, P, \& Driscoll, L. (2010). A tripartite perspective of social capital and its access by high school dropouts. Education and Urban Society, 42(5), 499-521.

Ensminger, M., \& Slusarcick, A,. (1992). Paths to high school graduation or dropout: a longitudinal study of a first-grade cohort. Sociology of Education, 65(2), 95-113.

Farrar, E., Neufeld, B., \& Miles, M. (1984). Effective schools programs in high schools: social promotion or movement by merit? The Phi Delta Kappan, 65(10), 701-706. 
Fanguy, J., \& Mathis, R. (2012). Psychosocial fallout from grade retention: Implication for educators. Delta Journal of Education, 2(2), 69-82.

Fiore, S.M., Graesser, A., Greiff, S., Griffin, P., Gong, B., Kyllonen, P. ...von Davier, A. (2017) Collaborative problem solving: Considerations for the National Assessment of Educational Progress (Tech. Rep.). Washington, DC: National Center for Educational Statistics.

Hernandez-Tutop, J. (2012). Social promotion or grade repetition: What's best for the $21^{\text {st }}$ century student? Retrieved from ERIC database. (ED532287)

Hill, N. \& Tyson, D. (2009) Parental Involvement in middle school: A meata-analytic assessment of the strategies that promote achievement. Developmental Psychology, 45, 740-763.

Hill, N., Witherspoon, D., \& Bartz, D. (2018) Parental involvement in education during middle school: Perspectives of ethnically diverse parents, teachers, and students, The Journal of Educational Research, 111(1), 12-27.

Hughes, J. N., West, S. G., Kim, H., \& Bauer, S. (2017). Effect of Early Grade Retention on School Completion: A Prospective Study. Journal of Educational Psychology. Advance online publication. http://dx.doi.org/10.1037/edu0000243

Jacob, B., \& Lefgren, L. (2004). Remedial education and student achievement: A regressiondiscontinuity analysis. The Review of economics and Statistics, 86(1):226-244.

Jacob, B., \& Lefgren, L. (2009). The effect of grade retention on high school completion. American Economic Journal: Applied Economics, 1(3):33-58. 
Jimerson, S., \& Kaufman, A. (2003). Reading, writing, and retention: a primer on grade retention. The Reading Teacher, 56(7), 622-635.

Jimerson, S., Pletcher, S., \& Graydon, K. (2006). Beyond grade retention and social promotion: promoting the social and academic competence of students. Psychology in the Schools, 43(1), 85-97.

Jimerson, S., \& Renshaw, T. (2012). Retention and Social Promotion. Principal Leadership,13(1), 12-16

Kaplan, D., Peck, B., \& Kaplan, W. (1997). Decomposing the academic failure-dropout relationship: a longitudinal analysis. The Journal of Educational Research, 90(6), 331-343.

Klapproth, F., Schaltz, P., Brunner, M., Keller, U., Fischbach, A., Ugen, S., \& Martin, E. (2016). Short-term and medium-term effects of grade retention in secondary school on academic achievement and pyschosocial outcome variables. Learning and Individual Difference 50, 182194

Lorence, J. (2014). Third-grade retention and reading achievement in Texas: A nine year panel study. Social Science research, 48, 1-19.

Lloyd, D. (1978). Prediction of school failure from third-grade data. Educational and Psychological Measurement, 38, 1193-1200.

Lynch, M. (2014). The True Costs of Social Promotion and Retention. International Journal of Progressive Educaiton, 10 (3), 6-17. 
Muller, C. (1993) Parent involvement and academic achievement: An analysis of family resources available to the child. In B. Schneider \& J.S. Coleman (Eds.), Boulder, CO: Westview Press.

Nelson-Royes A. (2013). Tutors Can Improve Students' Reading Skills. Reading Improvement, $50(2) 48-53$.

Owings, W., \& Kaplan, L. (2001). Standards, retention, and social promotion. NASSP Bulletin, $85(629), 57-66$.

Picklo, D., \& Christenson, S. (2005). Alternatives to retention and social promotion: the availability of instructional options. Remedial and Special Education, 26(5), 258-268.

Roderick, M. (1994). Grade retention and school dropout: investigating the association. American Educational Research Journal, 31(1), 729-759.

Schwerdt, G. \& West, M. R. (2012). The effects of grade retention on student outcomes over time: Regression discontinuity evidence from Florida. (Research Report No. PEPG 12-09) Retrieved from Harvard Kennedy School website: www.hks.harvard.edu/pepg/

Song, Y., Loewenstein, G., \& Shi, Y. (2018) Heterogeneous effects of peer tutoring: Evidence from rural Chinese middle Schools. Research in Economics, 72(1) 33-48

Smith, C. M. (2013). Elementary school grade retention: A qualitative study of high school seniors' perception of being held back. Unpublished Dissertation. Presented Graduate School of Western Carolina University. Retrieved http://libres.uncg.edu/ir/wcu/f/smith2013.pdf 
Vitaro, F., Brendgen, M., \& Tremblay, R. (1999). Prevention of school dropout through the reduction of disruptive behaviors and school failure in elementary school. Journal of School Psychology, 37(2), 205-226. 
Survey Results

\begin{tabular}{|c|c|c|c|c|c|}
\hline Freshman & $64.6 \% 104$ & & & & \\
\hline Sophomore & $23.6 \% 38$ & & & & \\
\hline Junior & $118 \% 19$ & & & & \\
\hline Senior & $0.0 \% 0$ & & & & \\
\hline Male & $47.2 \% 76$ & & & & \\
\hline \multirow[t]{2}{*}{ Female } & $52.3 \% 85$ & & & & \\
\hline & $\begin{array}{l}\text { Strongly } \\
\text { Agree }\end{array}$ & Agree & Undecided & Disgree & $\begin{array}{l}\text { Strongly } \\
\text { Disagree }\end{array}$ \\
\hline $\begin{array}{l}\text { 1) The possibility of failing motivates } \\
\text { students to work harder. }\end{array}$ & $23.6 \%(38)$ & $\begin{array}{l}64.6 \% \\
(104)\end{array}$ & $5.6 \%(9)$ & $0.0 \%(0)$ & $6.2 \%(10)$ \\
\hline $\begin{array}{l}\text { 2) Holding students who fail back a grade } \\
\text { improves their long term chance for success. }\end{array}$ & $11.8 \%(19)$ & $\begin{array}{l}17.4 \% \\
(28)\end{array}$ & $35.4 \%(57)$ & $\begin{array}{l}23.6 \% \\
(38)\end{array}$ & $14.9 \%(24)$ \\
\hline $\begin{array}{l}\text { 3) Students who are retained are more likely } \\
\text { to drop out of high school. }\end{array}$ & $6.2 \%(10)$ & $\begin{array}{l}42.9 \% \\
(69)\end{array}$ & $29.8 \%(48)$ & $\begin{array}{l}19.2 \% \\
(31)\end{array}$ & $1.8 \%(3)$ \\
\hline $\begin{array}{l}\text { 4) Home life affects how a student does at } \\
\text { school. }\end{array}$ & $53.4 \%(86)$ & $\begin{array}{l}36.6 \% \\
(59)\end{array}$ & $7.4 \%(12)$ & $2.5 \%(4)$ & $0.0 \%(0)$ \\
\hline $\begin{array}{l}\text { 5) After school tutoring helps students who } \\
\text { are failing. }\end{array}$ & $44.7 \%(72)$ & $\begin{array}{l}28.0 \% \\
(45)\end{array}$ & $27.3 \%(44)$ & $0.0 \%(0)$ & $0.0 \%(0)$ \\
\hline $\begin{array}{l}\text { 6) Summer school helps students who are } \\
\text { failing. }\end{array}$ & $42.2 \%(68)$ & $\begin{array}{l}33.5 \% \\
(54)\end{array}$ & $16.1 \%(26)$ & $0.0 \%(0)$ & $0.0 \%(0)$ \\
\hline $\begin{array}{l}\text { 7) Parent's attitude towards school affects } \\
\text { how a student does. }\end{array}$ & $54.1 \%(87)$ & $\begin{array}{l}39.1 \% \\
(63)\end{array}$ & $6.8 \%(11)$ & $0.0 \%(0)$ & $0.0 \%(0)$ \\
\hline $\begin{array}{l}\text { 8) When a student fails one year, they are } \\
\text { more likely to fail in the future. }\end{array}$ & $7.4 \%(12)$ & $\begin{array}{l}13.0 \% \\
(21)\end{array}$ & $25.4 \%(41)$ & $\begin{array}{l}33.5 \% \\
(54)\end{array}$ & $20.5 \%(33)$ \\
\hline $\begin{array}{l}\text { 9) When a student fails one year and is } \\
\text { promoted, they expect to pass regardless of } \\
\text { grade. }\end{array}$ & $21.7 \%(35)$ & $\begin{array}{l}44.7 \% \\
(66)\end{array}$ & $30.4 \%$ (49) & $6.8 \%(11)$ & $0.0 \%(0)$ \\
\hline $\begin{array}{l}\text { 10) The switch from middle school to high } \\
\text { school is difficult. }\end{array}$ & $0.0 \%(0)$ & $\begin{array}{l}24.8 \% \\
(40)\end{array}$ & $11.8 \%(19)$ & $37.9(61)$ & $25.4 \%(41)$ \\
\hline $\begin{array}{l}\text { 11) Promoting students who fail lessens the } \\
\text { value of education }\end{array}$ & $51.6 \%(83)$ & $\begin{array}{l}27.3 \% \\
(44)\end{array}$ & $5.0 \%(8)$ & $\begin{array}{l}16.1 \% \\
(26)\end{array}$ & $0.0 \%(0)$ \\
\hline $\begin{array}{l}\text { 12) Students who fail freshman year usually } \\
\text { do not graduate. }\end{array}$ & $3.7 \%(6)$ & $\begin{array}{l}13.0 \% \\
(21)\end{array}$ & $19.2 \%(31)$ & $\begin{array}{l}47.8 \% \\
(77)\end{array}$ & $16.1 \%(26)$ \\
\hline $\begin{array}{l}\text { 13) It is better to promote a failing student } \\
\text { than retain them. }\end{array}$ & $0.0 \%(0)$ & $\begin{array}{l}11.8 \% \\
(19)\end{array}$ & $26.7 \%(43)$ & $\begin{array}{l}48.4 \% \\
(78)\end{array}$ & $13.0 \%(13)$ \\
\hline $\begin{array}{l}\text { 14) Promoting a student who failed a class } \\
\text { helps the student. }\end{array}$ & $6.2 \%(10)$ & $\begin{array}{l}19.9 \% \\
(32)\end{array}$ & $18.0 \%(29)$ & $\begin{array}{l}47.2 \% \\
(76)\end{array}$ & $8.7 \%(1)$ \\
\hline 15) Failing hurts students' self-esteem. & $34.8 \%(56)$ & $\begin{array}{l}31.7 \% \\
(51)\end{array}$ & $33.5 \%(54)$ & $0.0 \%(0)$ & $0.0 \%(0)$ \\
\hline 16) Poor students are more likely to fail. & $8.7 \%(14)$ & $\begin{array}{l}14.9 \% \\
(24)\end{array}$ & $3.7 \%(4)$ & $36.0 \%(58)$ & $37.9 \%(61)$ \\
\hline $\begin{array}{l}\text { 17) Students who fail classes should be made } \\
\text { to retake them. }\end{array}$ & $30.4 \%(49)$ & $\begin{array}{l}28.0 \% \\
(45)\end{array}$ & $34.7(56)$ & $6.8 \%(11)$ & $0.0 \%(0)$ \\
\hline
\end{tabular}




\begin{tabular}{|l|l|l|l|l|l|}
\hline $\begin{array}{l}\text { 18) Students who fail state tests (EOGs or } \\
\text { EOCs) should retake the class. }\end{array}$ & $31.7 \%(51)$ & $\begin{array}{l}41.0 \% \\
(66)\end{array}$ & $24.2 \%(39)$ & $0.0 \%(0)$ & $3.1 \%(5)$ \\
\hline $\begin{array}{l}\text { 19) When a student fails, the teacher is to } \\
\text { blame. }\end{array}$ & $0.0 \%(0)$ & $\begin{array}{l}15.5 \% \\
(25)\end{array}$ & $11.8 \%(19)$ & $\begin{array}{l}50.9 \% \\
(82)\end{array}$ & $21.7 \%(35)$ \\
\hline $\begin{array}{l}\text { 20) When a student fails, the parent is to } \\
\text { blame. }\end{array}$ & $0.0 \%(0)$ & $\begin{array}{l}10.6 \% \\
(17)\end{array}$ & $13.7 \%(22)$ & $\begin{array}{l}31.7 \% \\
(51)\end{array}$ & $44.1 \%(71)$ \\
\hline & $24.2 \%(39)$ & $\begin{array}{l}47.8 \% \\
(77)\end{array}$ & $16.1 \%(26)$ & $\begin{array}{l}11.1 \% \\
(18)\end{array}$ & $0.7 \%(1)$ \\
\hline $\begin{array}{l}\text { 21) When a student fails, it is their fault. } \\
\text { 22) Elementary School prepared me for } \\
\text { Middle School. }\end{array}$ & $21.7 \%(35)$ & $\begin{array}{l}20.4 \% \\
(33)\end{array}$ & $29.8 \%(48)$ & $\begin{array}{l}28.0 \% \\
(45)\end{array}$ & $0.0 \%(0)$ \\
\hline $\begin{array}{l}\text { 23) Middle School prepared me for High } \\
\text { School. }\end{array}$ & $\begin{array}{l}64.6 \% \\
(104)\end{array}$ & $\begin{array}{l}27.3 \% \\
(44)\end{array}$ & $8.1 \%(13)$ & $0.0 \%(0)$ & $0.0 \%(0)$ \\
\hline $\begin{array}{l}\text { 24) High School is doing a good job preparing } \\
\text { me for college and obtaining a job. }\end{array}$ & $58.4 \%(94)$ & $\begin{array}{l}41.6 \% \\
(67)\end{array}$ & $0.0 \%(0)$ & $0.0 \%(0)$ & $0.0 \%(0)$ \\
\hline
\end{tabular}

Answers to the questions "What can a school system do to help students who fail a class?"

Give them tutoring for the things that they are failing in. Offer them to take the class again.

They can require students to attend morning and after class tutoring

Help and tutor them as much as possible.

I truly can't say but I think they should provide as much as they can. And take more none corporation look at education and center it on the job they want in the future

Continue doing what they're doing already. I don't think anything is wrong with the method that is being used. I think after school tutoring, summer school, and retaking classes are a very effective ways of helping failing students.

The school system can help by motivating the students in ways that they will want to succeed and pass the class. The school system should also only allow teachers with better expertise to teach the students that are struggling.

A school system can locate their weaknesses and try to better them before taking the whole subject on them as a whole.

First in forcing the school rules, and have high expectations for students and not giving petty points. Raise the bar more!!! Punish them and hold them responsible

Don't promote them because by doing so, the student becomes content with failing. if he/she didn't put in the work to pass the class, they should be made aware of the failure.

Figure out more about the person's home life. The school needs to be educated about the student's home life so they have the best possible understanding of the child and the best possible way to teach them. It is important the child receives the proper teaching style. What works for one child or a majority of children may not work for others. 
When a student fails a class there should be no psychological punishment from a teacher or parent. The student should be worked with and encouraged to do their best, but they should be expected to retake the fail course and acquire a passing grade. There should be remedial courses if it is felt the student needs them.

Pay more attention to that student motivating him to pass the class providing informational help needed.

They could give them a study hall for the subject if they only failed by a little bit, but if it was no effort what so ever they should sit in the class the next year.

Figure out why they failed the class and work from there.

They can offer credit recovery, where instead of having to take the entire class over again they only have to go after school and for a couple weeks and learn it again and retake the test.

They could make them take a shorter version of that class during after-school hours in order to fully understand the subject better.

Hold the failing student back. The real damage comes from a false image; if they are allowed to continue after failing a class, they may believe their abilities are sufficient, when those abilities are really not.

This idea is kinda long and complicated. The idea is to retain the students who fail to have a counselor meeting. Then the student and counselor sit down and seriously discuss how the student feels and what they feel would help them to excel. Then the counselor and student's parents should be talked to and evaluated to understand the kids' home life the help they want and are not just given.

Give them more days for tutoring

They can offer programs that can help them to obtain the knowledge they need in order to pass the class. Offer more one on one time with the student would also better help the student to pass, even though most school systems offer this, it's up to the student to take these opportunities.

Do more tutoring lessons and get more teachers involved with helping their students pass

I think they should help more than what they're doing, because some students don't have a way back home if they stay after school to get help, and don't have a way to get to school earlier for morning tutoring.

The school system can be more positive about it and try even harder to build their self-esteem. Instead of just failing them and making them take the class over again without even figuring out what the problem was, they should talk to them about why the failed and how the student can make sure they don't fail next time. Then make sure they get the extra help they need in the class.

I think they should start making tutoring a mandatory thing for any student who's grade is an certain average. Retain them. Don't promote them. 
The school system can offer extra tutoring and the school system should allow the student to retake the class they failed.

Answers to the question "What can a school do to prevent students from failing a class?"

Give them extra time and help.

Pay more attention to individuals instead of group studies

Be more social to them, let them know that they are here to help in any way.

I think all that could possibly be provided has already been provided. Most of the time it's the students fault why they are failing, simply because we as individuals have a hard time paying attention. But sometimes in some cases teachers can also be at fault for not explaining enough and moving too fast for students that don't comprehend at a fast paste.

I feel the school do as much as they can to help prevent a student from failing.

Use more incentives and try to motivate them

A school should have better incentives for passing a class, so students understand how important it is to pass a class and eventually graduate. The school should also make sure that the teachers they hire are competent in teaching a range of different types of students, from struggling students to successful students.

Bring back the paddle

Provide extra work, such as, tutoring and motivators like rewards that motivates people to better.

Make the student aware and also contact parents and have meetings with the guardian, student, and the principal. Make sure the student understands that education is free, and he/she should take the opportunity seriously. Express how hard it is to do anything if you don't have an education.

* Rewards for passing * Punishment for failing. Largely, the failure or success is based on the attitude of the student alone. A school will not necessarily change the attitude of the child. They can only help....

Extra credit should be given to students who are doing their best in the class and wants the extra credit. The teacher should speak with the student and their parents to come up with a plan to help the student succeed and to whatever it is that is decided whether it is extra tutoring or removal from the class during tests. If the student sincerely wants to pass the class and is willing to work and put effort towards it, everyone around them should do the same or at least aid them in their attempt.

To encourage the teachers to teach only the information that will be useful depending on the student's major. a lot a times the students fail classes is because they aren't interested in it. 
If they put forth an effort teachers should offer extra credit, and before school and after school tutoring. Make them take summer classes

Offer extra credit. More time to make up assignments. Let students make up work that they just didn't turn in for whatever reason. Offer tutoring during school hours.

The school should offer an hour study hall per day for students and make it mandatory that they go to it. It could be during the school day.

Offer as much after-school tutoring as possible and motivate students to come by offering extra credit to those who attend.

Find methods to teach new learning styles, as the jump taken from normal to honors to AP may frustrated some students. The work excepted varies highly between the different classes.

The school could offer more tutoring after school. The school could also offer to hire older students who are proven to know the material to help the failing kids. This would offer a job to the kids and would cause those who need money to study and learn the material to help teach.

Try to inspire them individually to do a good job

As mentioned in the above statement, they can offer more one on one help with the student, which can sometimes be difficult because of the number of students in a class, but it's also up to the student to do their work, so they can pass the class.

Motivate students to do good in school as far as the school as a whole and do hands-on skills to help them pass.

Make sure you have good teachers who care about their students inside of class and outside of class because your home life can be a big reflection of your grades. If there are problems at home then you will more than likely have problems in school. Then just work with your students and keep them updated regularly about their grades and not just a progress report every 3 weeks because by the time you get that first progress report you will only get one more before you receive your final grade, so if you are updated like once a week then you can know what you're missing and be able to make it up quicker and it won't build up on you over 3 weeks then you would have to do all your normal work plus a lot of makeup work.

They should make the classes smaller because some students aren't getting the attention that they need to learn. Offer tutoring. Study halls set aside as a class. 